\title{
Vertical and onshore-offshore distributional patterns of tuna larvae in relation to physical habitat features
}

\author{
George W. Boehlert ${ }^{1,2, *}$, Bruce C. Mundy ${ }^{1}$ \\ ${ }^{1}$ Honolulu Laboratory, Southwest Fisheries Science Center, National Marine Fisheries Service, 2570 Dole St., \\ Honolulu, Hawaii 96822-2396, USA \\ ${ }^{2}$ Joint Institute of Marine and Atmospheric Research, University of Hawaii, Honolulu, Hawaii 96922, USA
}

\begin{abstract}
The seasonal and spatial distributions of larval scombrids in waters off Oahu, Hawaii, were studied in September and December 1985 and April and June 1986 to determine vertical and onshore-offshore patterns. Horizontal distribution was resolved by sampling transects of 3 stations on the windward (east; $3.7,9.3$, and $27.8 \mathrm{~km}$ offshore) and leeward (west; $1.8,9.3$, and $27.8 \mathrm{~km}$ offshore) sides of the island. Vertical distribution was resolved by sampling with MOCNESS and Manta nets in 8 depth strata $(0$ to $80 \mathrm{~m})$ at the 2 nearshore stations and 9 depth strata $(0$ to $200 \mathrm{~m})$ at the 4 offshore stations. Scombrid larvae were abundant in all months except December. Collections in September and June were dominated by Thunnus spp.; about half were large enough to be identified to species and were predominantly $T$. albacares. Thunnus spp. generally were most abundant closest to shore on the leeward side of the island. Larval Thunnus were not taken at $>60 \mathrm{~m}$, were most abundant in the upper $20 \mathrm{~m}$, and were captured in the neuston at night but rarely in daytime. The other 2 dominant larval scombrids, Katsuwonus pelamis and Auxis spp., were most abundant in slightly deeper water. $K$. pelamis were most abundant at offshore stations, but Auxis spp. showed no clear onshore-offshore pattern. In April, Auxis spp. were most abundant and comprised over $99 \%$ of all larval scombrids. Diel vertical distribution patterns were not consistent between cruises or sides of the island for any species studied. No evidence was found for diel migratory behavior. The physical structure of the water column, particularly temperature and salinity, altered the spatial and temporal distribution patterns of larvae on short time and space scales and also on the seasonal scale. Seasonal patterns of spawning were likely dependent upon availability of appropriate thermal habitat. Larval Thunnus spp. and K. pelamis, in particular, were abundant only when temperatures were relatively warm. Auxis spp. larvae were found over a wider range of temperature than were the other genera. We suggest that the high concentrations of scombrid larvae, particularly Thunnus spp., near islands may be related to habitat characteristics that promote higher larval survival than in oceanic waters
\end{abstract}

KEY WORDS: Scombridae - Larval ecology Spawning · Islands · Hawaii

\section{INTRODUCTION}

Most studies on the distribution of tuna larvae have been conducted at scales of $>10 \mathrm{~km}$, in an attempt to document tuna spawning aggregations and locations (Matsumoto 1958, Kohno et al. 1985). Typically, these

\footnotetext{
- Present address: Pacific Fisheries Environmental Group, NMFS Southwest Fisheries Science Center, PO Box 831, Monterey, California 93942, USA
}

studies have used ring nets or other plankton gear and sampled obliquely or strictly in shallow water; the resultant densities of larvae were generally quite low (Matsumoto 1958, Strasburg 1960, Conand \& Richards $1981)$. In the open ocean, tunas may aggregate for spawning (Batalyants 1989, Koido \& Suzuki 1989), and very high densities of early larval southern bluefin tunas Thunnus maccoyii have been observed in a localized study site (Young \& Davis 1990). The vertical distribution of scombrid larvae has not received a great 
deal of attention. Most researchers have assumed that larvae occur primarily in warmer surface waters, and recent research has generally confirmed that tuna larvae are confined to the upper mixed layer and may disperse throughout that layer at night (Davis et al. 1990a).

Another feature of the spatial distribution of larval tuna is their abundance near land masses, particularly islands in tropical and subtropical regions. Miller (1979) observed densities of larval yellowfin tuna, Thunnus albacares, up to 2 orders of magnitude greater near leeward Oahu, Hawaii, than in offshore waters, and proposed a physical mechanism by which these high near-island concentrations might be maintained. Similarly, high concentrations of tuna larvae were found near French Polynesia by Leis et al. (1991), who suggested that spawning near islands may be a characteristic of some species, particularly in Thunnus. This may reach an extreme in $T$. tonggol, whose larvae are found only in nearshore waters (Nishikawa \& Ueyanagi 1991). On a larger scale, Miller (1979) also noted spatial variations in abundance of tuna larvae around the Hawaiian islands, with generally greater abundance on leeward, as opposed to windward, sides of the islands.

The spatial and seasonal distributions of tuna larvae are initially established by spawning, which in turn may be strongly influenced by temperature. Although tunas in tropical regions may spawn year-round, in subtropical areas such as Hawaii there are distinct spawning seasons (Matsumoto 1966, Uchida 1981, Nishikawa et al. 1985). For example, Katsuwonus pelamis spawn year-round near the equator but only

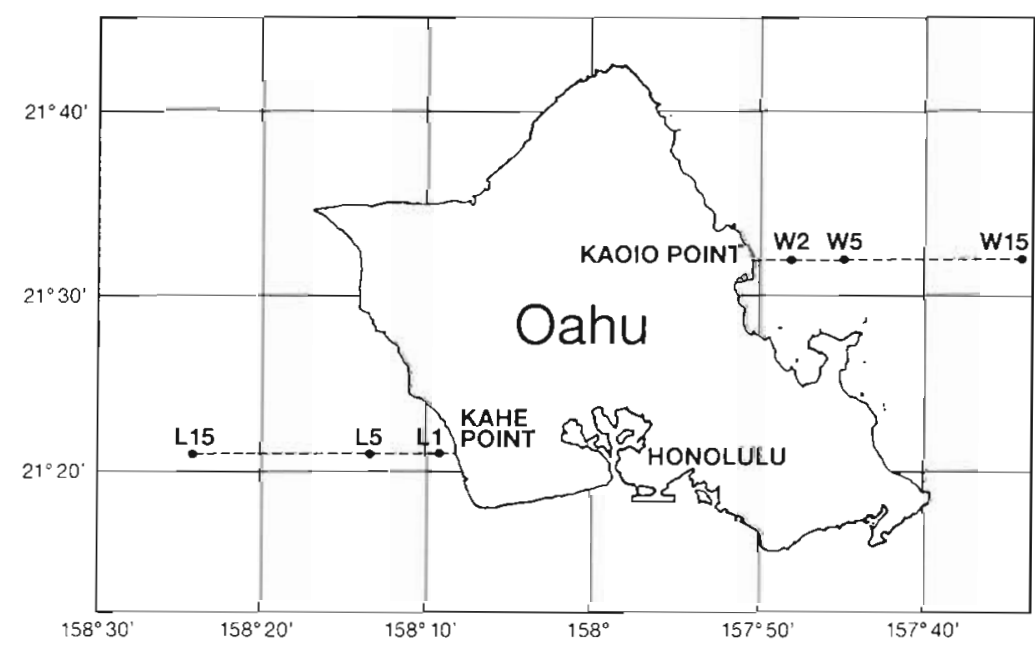

Fig. 1. Study site, Oahu, Hawaii. Station designations stand for leeward (L) and windward (W), and the associated number represents the distance offshore (in nautical miles). The nearshore windward station is twice as far offshore as that on the leeward side, but bottom depths are similar during late spring to early fall near Hawaii (Matsumoto $1966)_{i}$ their larvae are usually found at temperatures above 24 to $25^{\circ} \mathrm{C}$ although they have been collected at $22.1^{\circ} \mathrm{C}$ (Matsumoto et al. 1984). Thunnus albacares spawn year-round in the central Pacific (Matsumoto 1958) but only during March-August near Hawaii (Matsumoto 1966); larvae are usually found at temperatures above $24^{\circ} \mathrm{C}$ (Richards \& Simmons 1971). Few data on the spawning season of Auxis spp. in Hawaiian waters exist (Uchida 1981). Auxis spp. spawn yearround near the equator and at least in August off Oahu (Uchida 1981); larvae are found over a broader temperature range $\left(21.6\right.$ to $\left.30.5^{\circ} \mathrm{C}\right)$ than Thunnus or Katsuwonus (Richards \& Simmons 1971). The spawning seasons of $K$. pelamis and $T$. albacares near Hawaii begin when sea-surface temperatures are rising from the annual minima of 22.5 to $23.5^{\circ} \mathrm{C}$ and end when temperatures begin to decline from the maxima of 25.0 to $26.5^{\circ} \mathrm{C}$ (Seckel \& Yong 1977 ).

The present study was undertaken to provide detailed information on the seasonal, vertical, and onshore-offshore distribution of larval scombrids around the island of Oahu, Hawaii, and to characterize the physical features of larval habitat.

\section{MATERIALS AND METHODS}

Sampling. Four ichthyoplankton surveys were conducted aboard the NOAA ship 'Townsend Cromwell': 6 to 15 September 1985, 12 to 20 December 1985, 8 to 18 April 1986, and 24 June to 2 July 1986. East-west transects were established offshore from Kahe Point on the leeward (west) side and Kaoio Point on the windward (east) side of Oahu at latitudes $21^{\circ} 21^{\prime} \mathrm{N}$ and $21^{\circ} 32^{\prime} \mathrm{N}$, respectively. Sampling stations (Fig. 1) were located $1.8,9.3$, and $27.8 \mathrm{~km}$ from shore along the leeward side (locations L1, L5, and $L 15$, respectively) and $3.7,9.3$, and $27.8 \mathrm{~km}$ from shore along the windward side (W2, W5, W15). The distances from the island of the inshore stations of each transect differed because of bottom topography; these locations were chosen so both stations were over bottom depths of ca $100 \mathrm{~m}$. Larvae were sampled below the surface with a $1 \mathrm{~m}^{2}$ multiple openingclosing net and environmental sensing system (MOCNESS) (Wiebe et al. 1985) and at the sea surface with a $0.49 \mathrm{~m}^{2}$ Manta net (Brown \& Cheng 1981) modified to take surface samples to a depth of $0.7 \mathrm{~m}$; all nets were $0.333 \mathrm{~mm}$ Nitex mesh. Volume estimates for both gear 
types were based on mechanical flowmeter readings. Samples were taken in 8 depth strata (neuston, $0-10$, $10-20,20-30,30-40,40-50,50-60$, and $60-80 \mathrm{~m}$ depths) at each nearshore station (L1 or W2) and in 9 depth strata (neuston, 0-20, 20-40,40-60, 60-80, $80-100,100-120,120-160$, and $160-200 \mathrm{~m}$ depths) at the 4 offshore stations. MOCNESS hauls were of $12 \mathrm{~min}$ duration for each net (stratum), fished in a stepped oblique fashion from deep to shallow with mean tow speeds of approximately $75 \mathrm{~cm} \mathrm{~s}^{-1}$; neuston tows were $24 \mathrm{~min}$. Replicate tows were taken at each station day and night.

In the field, samples were fixed in $10 \%$ buffered formalin. Approximately 1 mo after each cruise, zooplankton displacement volumes were measured following Omori \& Ikeda (1984) and samples were transferred to $50 \%$ isopropyl alcohol. Only the first replicate sample was processed for the December, April, and June cruises, whereas both replicates were processed for the September cruise. All larval fishes were sorted from the whole samples under dissecting microscopes and stored in vials in alcohol. Standard lengths (or notochord lengths for preflexion larvae) of Thunnus spp. and Katsuwonus pelamis from leeward samples of the June 1986 cruise were measured with a dissecting microscope linked to a Biosonics Optical Pattern Recognition System

Larval identification. Larvae larger than ca $3.0 \mathrm{~mm}$ notochord or standard length (SL) were identified using the criteria of Nishikawa \& Rimmer (1987), and those smaller than $3.0 \mathrm{~mm}$ SL using Collette et al. (1984) and Fritzsche (1978). Acanthocybium larvae were identifiable at all sizes. Other scombrids approximately 2.5 to $3.0 \mathrm{~mm}$ SL were identified only as Auxis/Euthynnus, Katsuwonus, or Thunnus spp. Scombrid larvae smaller than approximately $2.5 \mathrm{~mm}$ SL were assigned to the unidentified Scombridae category. Auxis larvae were not identified to species or larval type, but 2 species, $A$. thazard and $A$. rochei, are known to occur in Hawaii. Thunnus larvae $>3.0 \mathrm{~mm}$ SL were identified to species by their pigment characters (Matsumoto et al. 1972, Nishikawa \& Rimmer 1987). These identifications are offered cautiously, because pigment may be more variable in these species than has been described based on identification of larger larvae by osteological (Richards \& Potthoff 1974) and electrophoretic characters (Graves et al. 1988). Our specimens of ' $T$. albacares' and ' $T$. obesus' are smaller than those identified by Richards \& Potthoff (1974) and Graves et al. (1988); we are uncertain whether the variability found in those studies is similar for larvae in our study. For this paper, only 4 principal taxa are analyzed: Auxis spp., Katsuwonus pelamis, Thunnus albacares, and Thunnus spp. (total, including $T$. albacares). Information on the other less abundant taxa is available in a data report from the authors.
Data analysis. Statistical analyses of larval densities (no. per $1000 \mathrm{~m}^{3}$ ) or abundance (no. per $100 \mathrm{~m}^{2}$ ) were generally made on log-transformed data. Larval densities or abundances reported for the September cruise are the means of both replicates. Densities related to specific environmental features or abundances used for comparisons of larval numbers among seasons use data from the first replicate only.

Larval densities were used for comparisons of vertical distribution to indicate possible diel migration. Day and night stations at the same date and location were compared if larval densities were sufficiently high. Low summed density values (less than 3 larvae $1000 \mathrm{~m}^{-3}$ for Auxis spp., Thunnus spp., and T. albacares and less than 4 larvae $1000 \mathrm{~m}^{-3}$ for Katsuwonus pelamis) were deleted. At the remaining stations, weighted mean depths of occurrence for each taxon were calculated by station location and day or night as follows: for each sample, the log of larval density was multiplied by the midpoint depth of the vertical stratum for that sample. These values were summed by station location separately for day and night, and the values were divided by the sum of the log-transformed densities for the same day or night station. The resulting day-night weighted depth values were compared using a Wilcoxon paired signed-rank test to determine whether systematic patterns of diel distribution were evident. Overall mean depths of occurrence were also calculated for each of the 4 taxa based on all positive stations.

Larval abundances were used for comparisons of onshore-offshore distribution. Abundances were calculated for each station by (1) multiplying the number of larvae in each depth stratum by the vertical extent of the stratum's depth range, (2) dividing these values by the sample volume, and (3) summing resultant values across all depth strata within a given station location by day or night; the result was multiplied by 100 to scale the value (to larvae per $100 \mathrm{~m}^{2}$ ). Because the vertical series sampled over the entire range of the scombrid vertical distribution, day and night samples were used as replicates of abundance at a given location. Potential avoidance-based differences between day and night samples were examined by analyzing the length frequency distribution of Thunnus spp. and Katsuwonus pelamis from leeward samples from the June 1986 cruise and also by pairwise comparison of day versus night abundances for each taxon.

Environmental data collected from the MOCNESS sensors were used during and after sampling. During sampling, real-time depth information was used to target the depth strata sampled. Salinity, temperature, and depth data were stored on disc at $4 \mathrm{~s}$ intervals. Sigma-t was calculated from standard formulas (Fofonoff \& Millard 1983). Profiles were made by aver- 
aging across $1 \mathrm{~m}$ depth bins. Physical environmental data from the Manta net tows were estimated by using data values for the shallowest depth sampled by the MOCNESS in the same sample series (typically 0 to $1 \mathrm{~m}$ ). Mean, minimum, and maximum values of $\mathrm{T}, \mathrm{S}$, and sigma-t were determined for each sample (by depth stratum) for statistical analysis.

\section{RESULTS}

\section{Seasonality of occurrence}

The abundance of larvae varied seasonally. In September 1985, collections were dominated by Thunnus spp. (Fig. 2), representing 227 of 365 scombrid larvae in the first replicate series. More than half were sufficiently large to be identified to species, and $95 \%$ of these were $T$. albacares. Larval Thunnus spp. were absent in December 1985 and April 1986 but again dominated the collections in June 1986. In June larvae were typically smaller, so only $19.3 \%$ were identified to species, and $90 \%$ of these were $T$. albacares. Katsuwonus pelamis showed a seasonal pattern similar to that of Thunnus spp. but were less abundant. Auxis spp. were rare in December, moderately abundant in September and June, but dominated the collections in April, when they represented 416 of the 421 scombrid larvae taken. Other scombrids taken in this study but not discussed further include Acanthocybium solandri (5 larvae in September, 6 in June), T. obesus (5 larvae in June), $T$. alalunga (9 larvae in September, 2 in June), and Euthynnus affinis (1 larva in September, 3 in December, and 1 in June).

Patchiness was relatively high, as is typical of scombrid larvae (Davis et al. 1990b). Sampling variability between replicate samples as estimated by the coeffi-

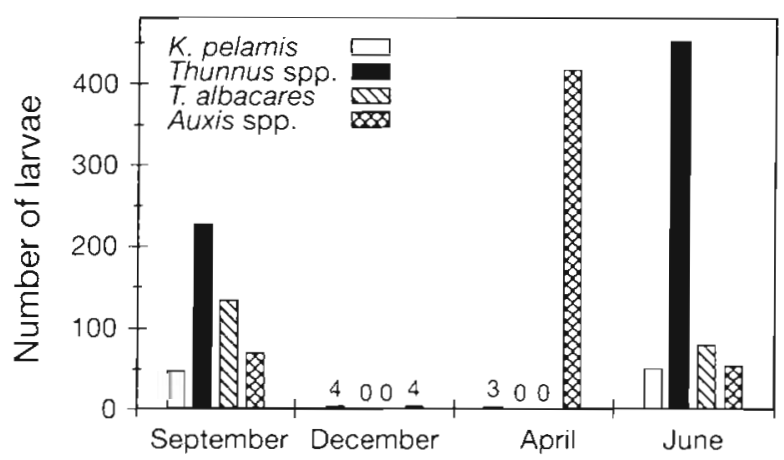

Fig. 2. Seasonality of larval scombrid occurrence around Oahu. Numbers represent the total larvae of each taxon captured in the first replicate series at all depths, including the neuston. Thunnus spp. represents all identified as well as unidentified specimens, and includes $T$. albacares cient of variation in the 104 pairs of samples in the September 1985 cruise showed mean values from 1.11 for Thunnus spp. to 1.33 for Auxis spp.; this is contrasted to values for all ichthyoplankton of 0.43 . Comparing horizontal scales of patchiness [Lloyd's (1967) index] using abundance (larvae per $100 \mathrm{~m}^{2}$ ), patchiness for a given species was generally least in those cruises when abundance was highest. Patchiness of Katsuwonus pelamis was generally least, $T$. albacares greatest, and Thunnus spp. and Auxis spp. intermediate.

Avoidance of the sampling gear was assessed by comparing abundance and larval lengths between day and night samples. Pairwise comparisons of day versus night larval abundances (by taxon) for cruises where the species were present showed no significant difference in abundance for any species (Wilcoxon signedrank test, $p>0.05$ ). To avoid effects of differences based upon onshore-offshore differences in length (see next section), only the nearshore station was used for comparing lengths of Thunnus and the 2 offshore stations for Katsuwonus pelamis. Lengths were not significantly different between day and night for either species (Mann-Whitney $U$-test, p > 0.05). Thus, avoidance was likely uniform across our sampling and not a factor for comparison of diel patterns.

\section{Onshore-offshore distribution patterns}

Vertical distribution patterns (see below) revealed that the sampling depth at all stations exceeded the vertical range of larval scombrids, which were restricted to the upper mixed layer. Thus, calculations of larval abundance (per $100 \mathrm{~m}^{2}$ ) were appropriate for examining the onshore-offshore patterns. The general pattern of larval abundance combining those cruises where the taxa were present (September, April and June for Auxis spp.; September and June for Katsuwonus pelamis and Thunnus spp.) reveals differences by taxa and by location (Fig. 3). No significant differences existed between leeward and windward overall abundance except for Thunnus spp. (Mann-Whitney $U$-test, $\mathrm{p}<0.05$ ). Abundance of Auxis spp. was similar at the 2 stations nearer to shore, and these were significantly greater than at the offshore station (MannWhitney $U$-test, $p<0.05)$. K. pelamis showed low abundance nearshore that increased offshore and Thunnus spp. showed the opposite trend, decreasing in abundance with increasing distance offshore (Kruskal-Wallis test, $\mathrm{p}<0.05$ ); while the trend for the latter species was evident on the leeward side, the nearshore windward station (W2) showed the lowest mean abundance of the 6 locations (Fig. 3). Larvae from the June 1986 leeward samples were significantly smaller at the nearshore station and larger offshore for 


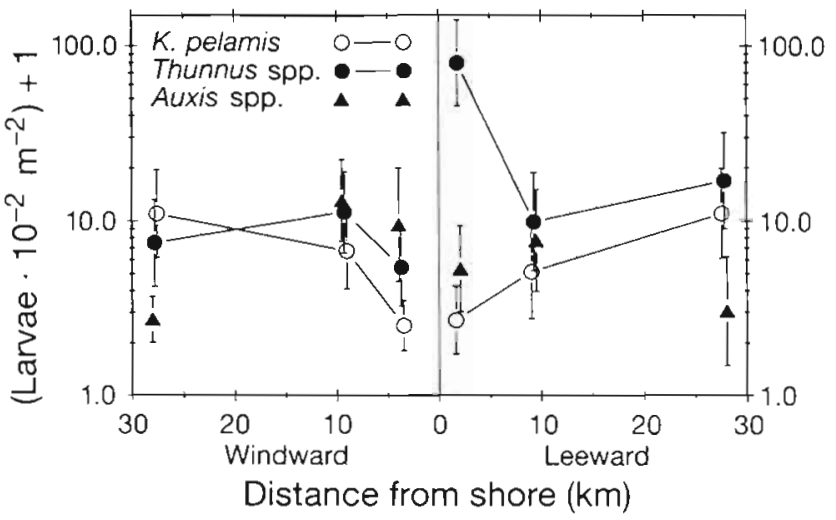

Fig. 3. Onshore-offshore distribution patterns of larval abundance (per $100 \mathrm{~m}^{2}$ ) for the 3 principal scombrid taxa. Data combine samples across cruises: for Auxis spp., each point includes data from September $1985(\mathrm{n}=4)$, April $(\mathrm{n}=2)$ and June $1986(\mathrm{n}=2)$; for Thunnus spp. and Katsuwonus pelamis, data are from September and June only. Error bars = $1 \mathrm{SE}$

Thunnus (Kruskal-Wallis test, $\mathrm{p}<0.001$ ) and $K$. pelamis $(\mathrm{p}=0.028)$.

\section{Vertical distribution patterns}

Day and night series at individual locations during each cruise were compared to determine whether diel vertical migration was evident. Within locations and cruises, specific examples of changes in the diel pattern of vertical distribution were evident, but were not consistent except for neuston samples, where larvae were very rare in day samples. Pairwise comparisons of day and night mean depths of occurrence (weighted by log of larval density) were not significantly different (Wilcoxon signed-rank test, $\mathrm{p}>0.10$ ) for any of the taxa suggesting that there was no detectable, consistent pattern of vertical migration. Thus, our description of vertical distribution was based upon combined day and night samples (Fig. 4).

The general patterns of vertical distribution are described by combining data separately for inshore stations (L1, W2) and offshore stations (L5, L15, W5, W15) because of different sampling resolution for the vertical strata. All scombrid larvae were generally restricted to the upper mixed layer at all stations. Larval Thunnus spp. were characterized by the shallowest distribution; they were not taken at depths $>64 \mathrm{~m}$ and were most abundant in the upper $20 \mathrm{~m}$ (weighted mean $=15.0 \mathrm{~m}$; Table 1 ). They were captured in the neuston at night but rarely in daytime. Larval Katsuwonus pelamis were never taken at depths $>84 \mathrm{~m}$ and were rare in the neuston (Fig. 4), with the greatest density in the upper $40 \mathrm{~m}$ stratum in the offshore stations. $K$. pelamis had the greatest mean depth of occurrence of any of the scombrid taxa studied (Table 1). Larval Auxis spp. were found in water $<60 \mathrm{~m}$; the density in the neuston and the mean depth of occurrence were intermediate between those of Thunnus spp. and $K$. pelamis (Table 1).

More detailed patterns of vertical distribution are revealed in sample series off the leeward side during seasons of peak abundance for scombrid larvae. For larval Thunnus spp. in June (Fig. 5), increased abundance at the nearshore station relative to of fshore locations is evident. In this series, larvae are more abundant in daytime samples than at night; at the nearshore station, distribution was relatively uniform in the upper $40 \mathrm{~m}$, in opposition to the pattern for all June and September samples combined (Fig. 4); larvae were taken in the neuston only at night. Median lengths of larval Thunnus taken shallower than $20 \mathrm{~m}(3.02 \mathrm{~mm})$ at the June nearshore station were significantly greater than those collected deeper than $20 \mathrm{~m}(2.57 \mathrm{~mm}$; MannWhitney $U$-test, $p<0.001)$. Larval Katsuwonus pelamis in June (Fig. 6) are characteristically more abundant at

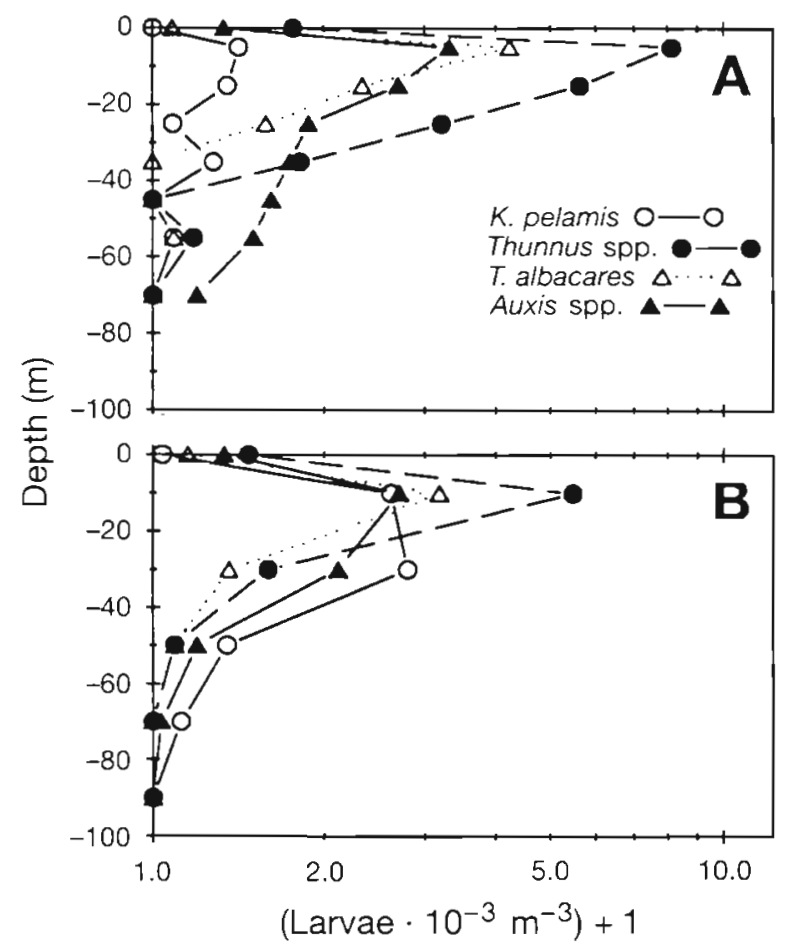

Fig. 4. Vertical distribution of scombrid larvae off Oahu. Values for Auxis spp. are means from cruises in September 1985, April 1986, and June 1986. Values for all other taxa are means from September 1985 and June 1986. Samples used to calculate the means include day and night, wind ward and leeward, and both replicates from the September cruise. (A) Nearshore stations (W2, L1); each point is the mean of 16 samples for Auxis spp. and 12 samples for the other taxa. (B) Offshore stations (W5, W15, L5, L15); each point is the mean of 32 samples for Auxis spp. and 24 samples for other taxa 
Table 1. Distribution of larvae of different taxa with respect to environmental factors. Values are based upon data from MOCNESS sensors collected at 4 s intervals. Data for Auxis spp. are based upon September 1985, April 1986, and June 1986 cruises for all depths shallower than $80 \mathrm{~m}(\mathrm{n}=288)$; data for the other taxa are based on September and June cruise, samples shallower than $80 \mathrm{~m}$ for Katsuwonus pelamis $(\mathrm{n}=216$ ) and $60 \mathrm{~m}$ for Thunnus ( $\mathrm{n}=180$ ). Mean values are weighted by log of larval density. N: total number of larvae. Pos. hauls: number of samples in which this taxon was taken. The range sampled is based upon all seasons and samples

\begin{tabular}{|c|c|c|c|c|c|}
\hline & Auxis spp. & Katsuwonus pelamis & Thunnus albacares & Thunnus spp. & Range sampled \\
\hline$N$ & 524 & 126 & 230 & 751 & - \\
\hline Pos. hauls & 76 & 53 & 45 & 66 & 520 \\
\hline \multicolumn{6}{|l|}{ Depth $(m)$} \\
\hline $\operatorname{Min}$ & 0.00 & 0.00 & 0.00 & 0.00 & 0.00 \\
\hline $\operatorname{Max}$ & 84.00 & 84.00 & 64.00 & 64.00 & 217.00 \\
\hline Mean & 22.23 & 25.75 & 14.53 & 14.98 & 62.40 \\
\hline SD & 3.17 & 3.80 & 3.22 & 2.72 & 53.35 \\
\hline \multicolumn{6}{|l|}{$\mathrm{T}\left({ }^{\circ} \mathrm{C}\right)$} \\
\hline Min & 21.88 & 22.00 & 24.19 & 24.19 & 16.04 \\
\hline $\operatorname{Max}$ & 27.20 & 27.20 & 27.52 & 27.52 & 27.52 \\
\hline Mean & 24.40 & 25.94 & 26.15 & 26.17 & 23.57 \\
\hline $\mathrm{SD}$ & 0.18 & 0.17 & 0.14 & 0.11 & 2.32 \\
\hline \multicolumn{6}{|l|}{$S(\%)$} \\
\hline Min & 34.69 & 34.74 & 34.74 & 34.74 & 34.59 \\
\hline $\operatorname{Max}$ & 35.32 & 35.31 & 35.18 & 35.18 & 35.47 \\
\hline Mean & 35.03 & 34.94 & 34.93 & 34.91 & 35.07 \\
\hline $\mathrm{SD}$ & 0.02 & 0.02 & 0.02 & 0.02 & 0.13 \\
\hline \multicolumn{6}{|l|}{ Sigma-t } \\
\hline Min & 22.59 & 22.59 & 22.52 & 22.52 & 22.52 \\
\hline $\operatorname{Max}$ & 24.46 & 24.43 & 24.22 & 24.22 & 25.57 \\
\hline Mean & 23.47 & 23.03 & 22.95 & 22.93 & 23.82 \\
\hline SD & 0.06 & 0.06 & 0.05 & 0.04 & 0.70 \\
\hline
\end{tabular}

the offshore stations in deeper water than Thunnus spp., with no larvae taken in neuston collections. There is a trend to deeper occurrence with increasing distance from shore. Median lengths of larval $K$. pelamis taken shallower than $20 \mathrm{~m}(4.54 \mathrm{~mm})$ were significantly greater than those taken deeper than $20 \mathrm{~m}$ (3.926 mm; $p=0.022)$. Larval Auxis spp. in April (Fig. 7) were least abundant at the offshore station but abundant both day and night at the 2 nearshore stations. Again, neustonic larvae were taken only at night.

\section{Relationship of larval distributions to physical features}

The distribution of the larval scombrids in this study was restricted to the upper mixed layer. Larvae were taken in tows where the minimum temperature ranged from $21.88^{\circ} \mathrm{C}$ for Auxis spp. to $24.19^{\circ} \mathrm{C}$ for Thunnus spp., and in tows where temperatures were at or near the maxima recorded in this study (Table 1). Although the ranges of salinity and sigma- $t$ were small, scombrid larvae were typically found in waters with lowest salinity and density (Table 1). Thus, the seasonality of spawning as well as the depth distribution of larvae around Oahu is likely related to availability of appropriate physical habitat characteristics.

Seasonal patterns of temperature, salinity, and sigma- $t$ in the upper $100 \mathrm{~m}$ of the water column are distinct (Fig. 8); they reflect general patterns around Oahu, where mean monthly temperatures are lowest in March and highest in September, with salinity minimum in June-July (Seckel \& Yong 1977). From the limited months we sampled, the deepest mixed layer was present in December and April, with shallower depths in September and June. At depths above $50 \mathrm{~m}$, seasonal temperatures were highest in September. Temperatures were coldest throughout the upper $100 \mathrm{~m}$ in April. Thunnus spp. and Katsuwonus pelamis occurred around Oahu only during September and June (Fig. 2), when water temperatures were warmest (Fig. 8). Auxis spp., on the other hand, had an unusual seasonal distribution pattern relative to the physical characteristics of the water column. They occurred in moderate numbers in September and June, were very rare $(n=4)$ in December, and most abundant in April (Fig. 2), when temperatures in the upper water column were the coldest of all seasons sampled (Fig. 8).

Changes in vertical distribution on short time scales also varied with physical factors. The most dramatic difference in diel distribution in a single day-night sample 


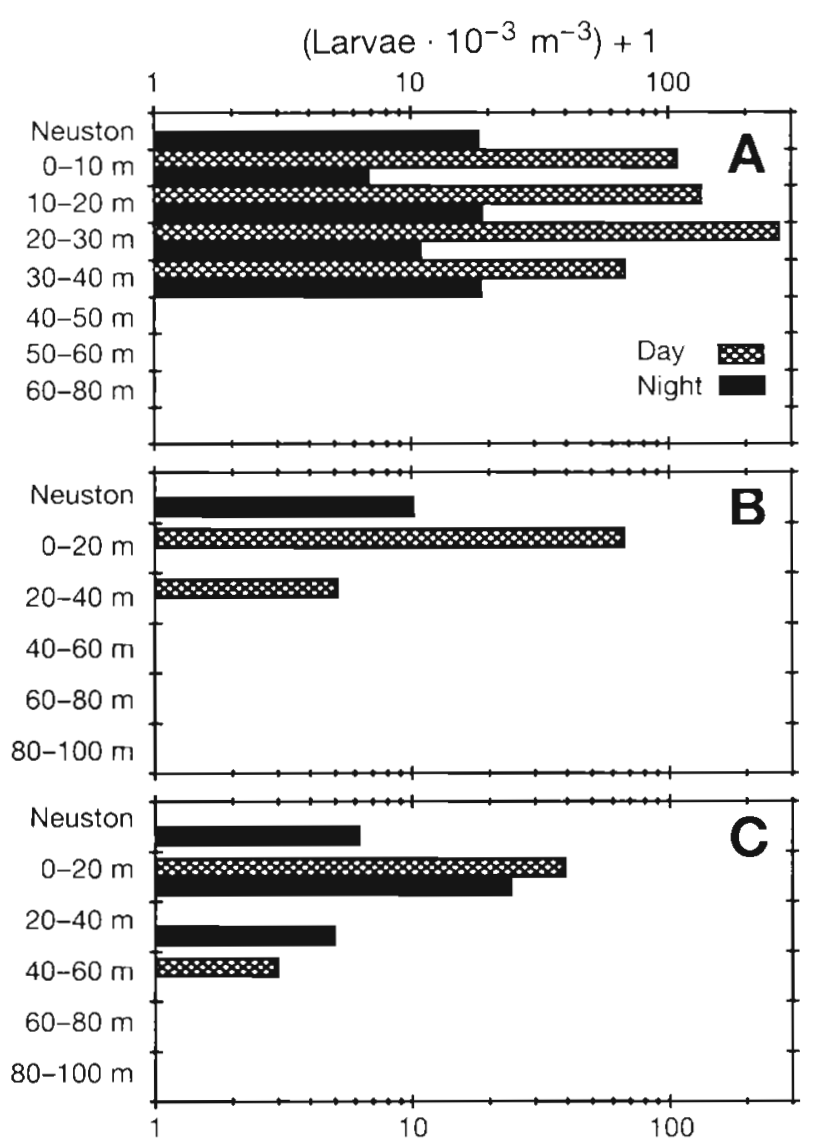

Fig. 5. Thunnus spp. Vertical and onshore-offshore distribution of larvae off leeward Oahu, June 1986. Each value represents a single sample. (A) Stn L1. (B) Stn L5. (C) Stn L15

pair was observed at the nearshore windward station in April, when a marked change in the vertical distribution of Auxis spp. larvae was evident. Larvae were most abundant in the 0 to $10 \mathrm{~m}$ stratum by day (weighted mean depth $16.88 \mathrm{~m}$ ), with only 1 larva taken deeper than $30 \mathrm{~m}$. At night, the vertical distribution pattern was broader, with maximum abundance in the 50 to $60 \mathrm{~m}$ stratum (weighted mean depth $33.78 \mathrm{~m}_{\text {i Fig. }}$ 9). The weighted mean depths at this station were the extremes (minimum for day series, maximum for night) for Auxis spp. on this cruise. Water temperature profiles taken concurrently were also quite different. Higher temperatures were evident at greater depths at night as compared to day samples. There was no remarkable change in wind speed associated with this period, so it is unlikely that the changes were due to wind-induced mixing. An intrusion of low salinity water was evident at 20 to $45 \mathrm{~m}$ depth in the daytime sample, however. Because this sample was taken coincidently with low tide, the low salinity water and relatively shallow thermocline may have been of nearshore origin, perhaps from nearby Kaneohe Bay. The night sample, taken $12 \mathrm{~h}$ later

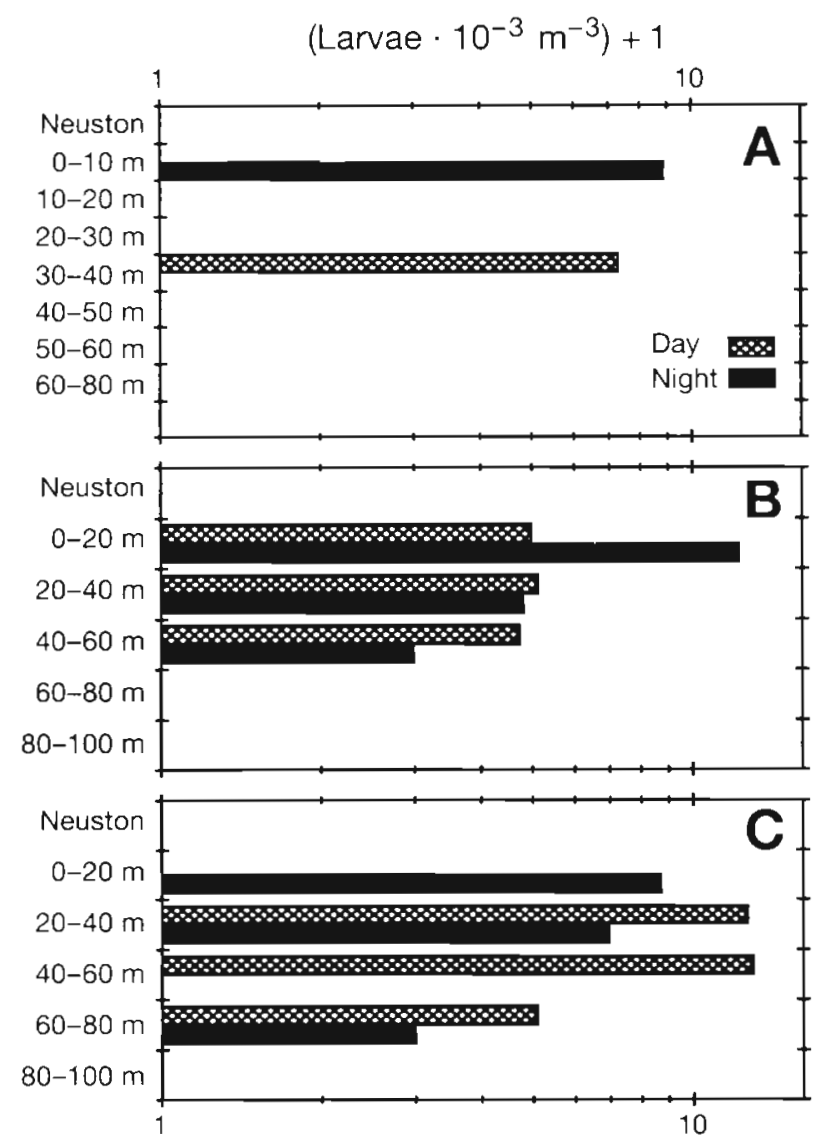

Fig. 6. Katsuwonus pelamis. Vertical and onshore-offshore distribution of larvae off leeward Oahu, June 1986. Each value represents a single sample. (A) Stn L1. (B) Stn L5. (C) Stn L15

at high tide, showed thermal and salinity profiles more characteristic of oceanic water. A transect of XBT profiles taken along $21^{\circ} 37^{\prime} \mathrm{N}$ (9 $\mathrm{km}$ north of the sampled transect) between the day and night samples showed an increase in the depth of the $22.5^{\circ} \mathrm{C}$ isotherm from $40 \mathrm{~m}$ at $6.3 \mathrm{~km}$ from shore to $85 \mathrm{~m}$ at $34.3 \mathrm{~km}$ from shore. This was consistent with the hypothesis that the daytime sample was more characteristic of nearshore water than the nighttime sample. Thus, the vertical distribution of larval Auxis spp. was clearly related to the vertical structure of the water column as opposed to depth or diel factors alone (Fig. 9). Advective replacement of the more nearshore water mass in daylight hours with more offshore water may account for the observed changes in depth distribution at this location.

Spatial differences in physical factors may also have influenced the vertical distribution and abundance of larvae. This was particularly evident in the relationship of temperature to larval abundance and vertical distribution of Thunnus spp. at leeward and windward nearshore stations. In September, Thunnus spp. were most abundant at night but uniformly more abundant 


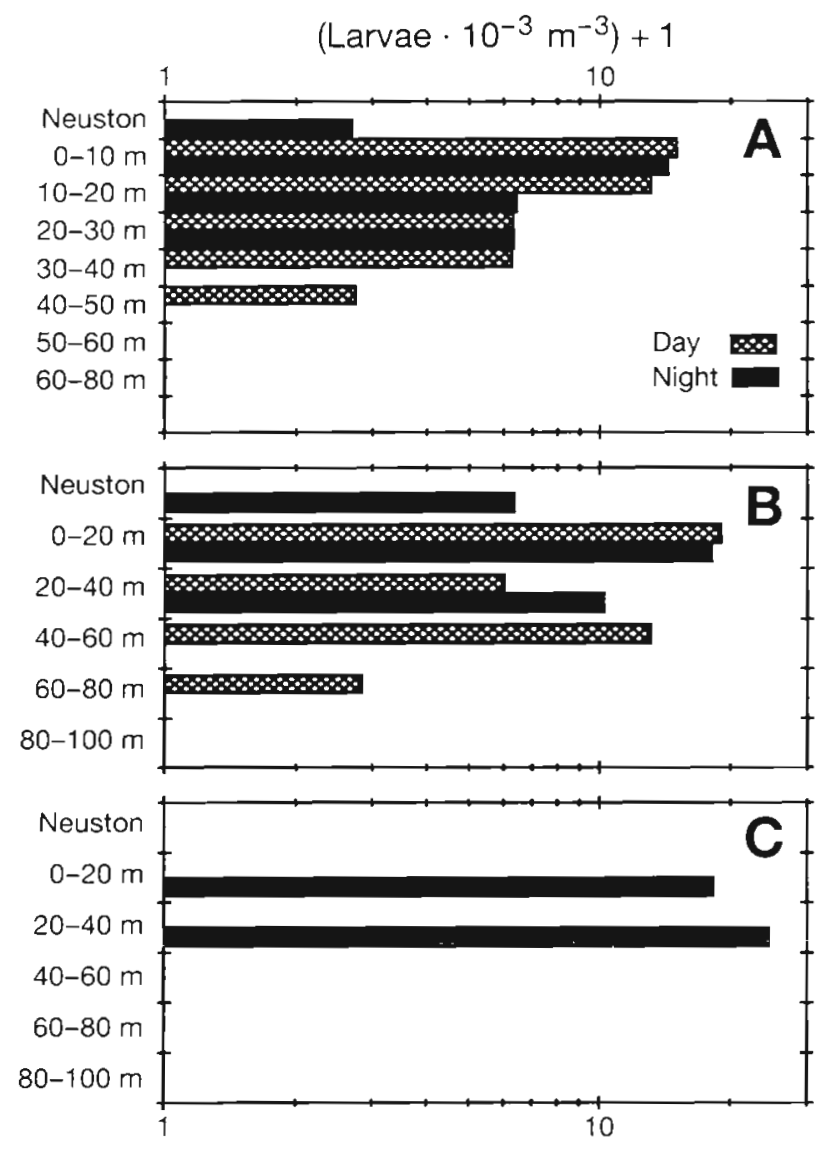

Fig. 7. Auxis spp. Vertical and onshore-offshore distribution of larvae off leeward Oahu, April 1986. Each value represents a single sample. (A) Stn L1. (B) Stn L5. (C) Stn L15

at the leeward station. Comparisons of vertical profiles revealed that larvae were restricted to the upper $30 \mathrm{~m}$, consistent with the relatively shallow thermocline in that month (Fig. 10). The temperature profile on the windward side was characteristic of open ocean conditions, with cooler, higher salinity water at the surface and a less distinct thermocline. The leeward station, by contrast, had warmer, low salinity water in the upper $30 \mathrm{~m}$, a much sharper thermocline, and temperatures lower than the windward station below that depth. Thunnus larvae were restricted to the warm, surface layer and were far more abundant at the warmer leeward station. In day samples taken at the same stations in June, the situation was similar although the thermocline was much deeper and the leeward station was characterized by water up to $1{ }^{\circ} \mathrm{C}$ warmer throughout the upper $80 \mathrm{~m}$ (Fig. 11). On the leeward side, larvae were much more abundant down to $40 \mathrm{~m}$, consistent with the deeper thermocline as compared to the September samples. The warm, low salinity pool in the leeward transect was evident in all cruises except December and extended seaward to the L15 station.

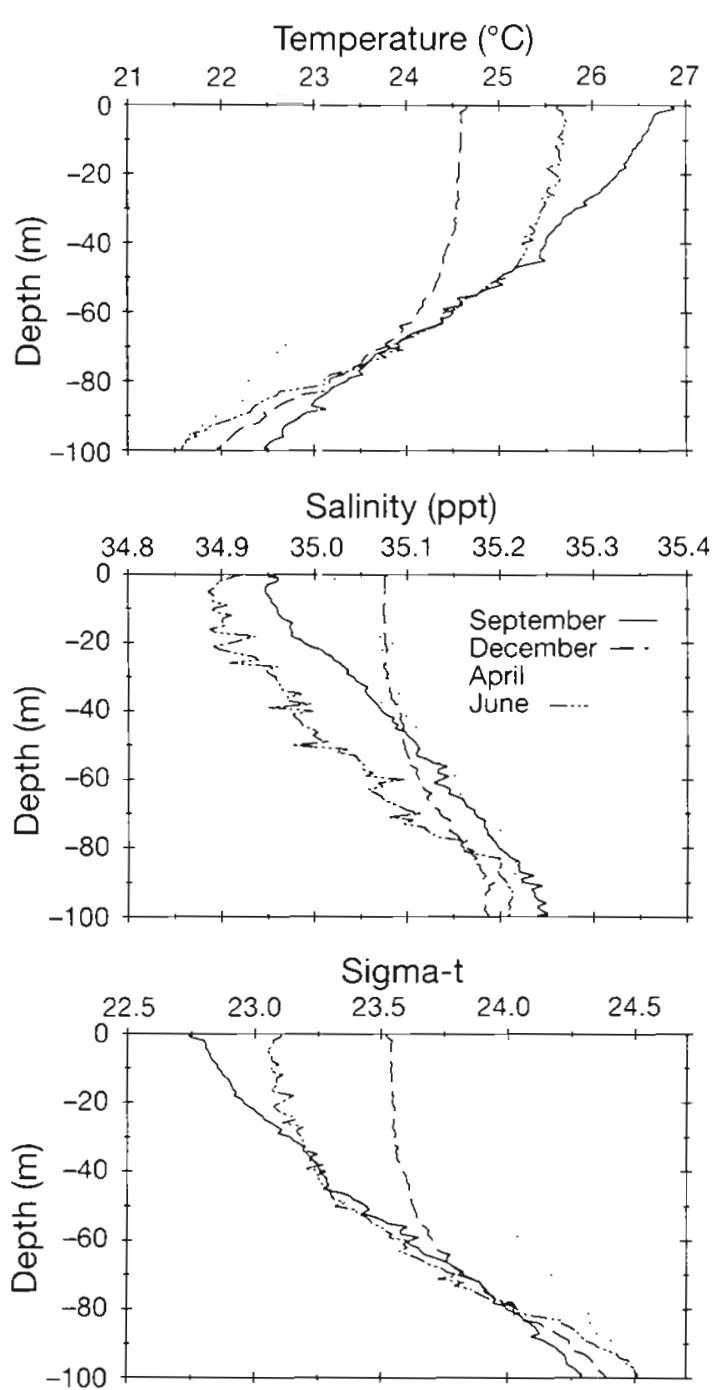

Fig. 8. Profiles of temperature, salinity, and density (sigma-t) for the 4 cruises. Mean values from all MOCNESS first replicate casts were used to construct these plots

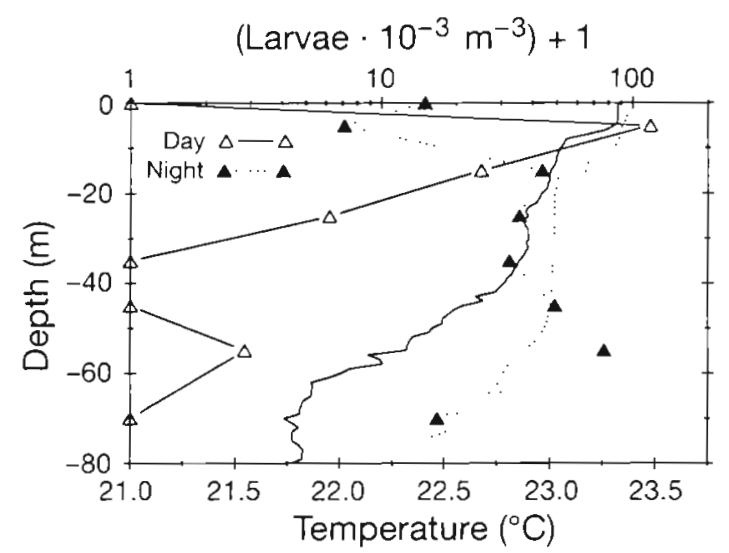

Fig. 9. Auxis spp. Distribution of larvae during day and night sampling at the inshore windward station (W2) during April 1986. Temperature data were taken with MOCNESS sensors concurrent with plankton samples 


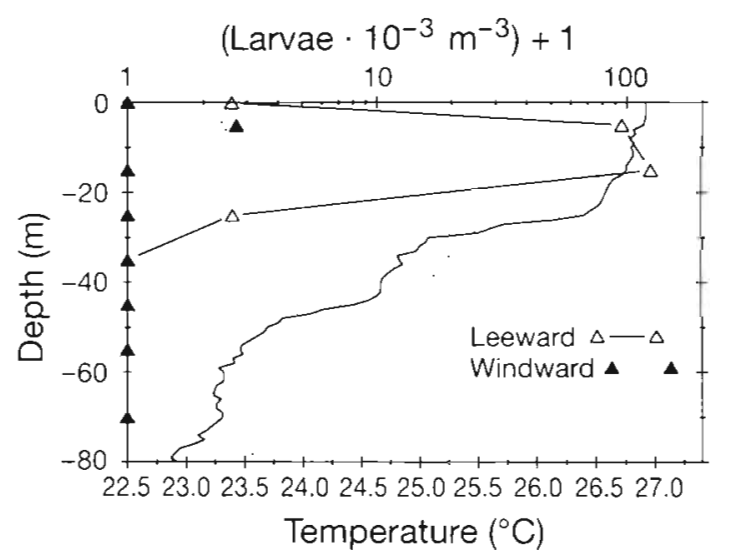

Fig. 10. Thunnus spp. Vertical distribution of larvae at windward and leeward nearshore stations (L1, W2) during night sampling in September 1985. Data from the first replicate are shown. Temperature data were taken with MOCNESS sensors concurrent with plankton samples

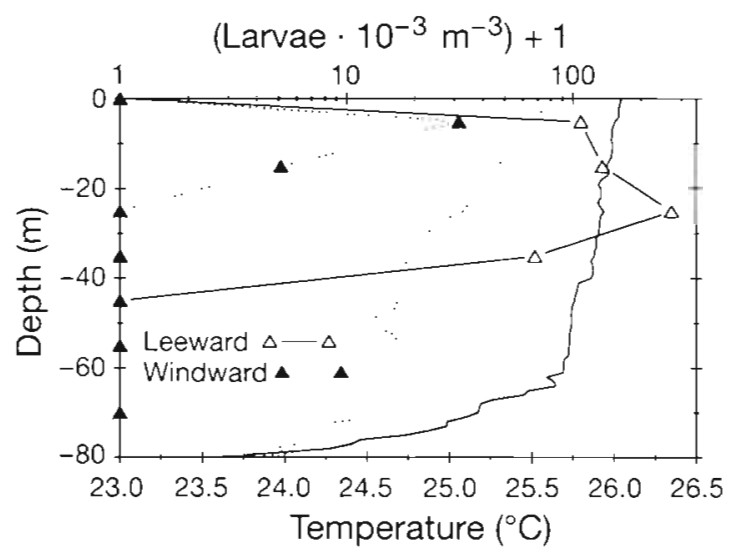

Fig. 11. Thunnus spp. Vertical distribution of larvae at windward and leeward nearshore stations (L1, W2) during day sampling in June 1986. Temperature data were taken with MOCNESS sensors concurrent with plankton samples

\section{DISCUSSION}

A variety of studies using different types of plankton sampling gear have shown that scombrid larvae occur primarily in the mixed layer and upper portion of the thermocline (Strasburg 1960, Davis et al. 1990a). The geographic occurrence of larvae (Nishikawa et al. 1985), however, suggests that spawning is distributed over wide areas and seasons in tropical and subtropical waters. Availability of appropriate spawning and larval habitat may be an important determinant of tuna spawning, both on temporal and spatial scales. Because Hawaii is at the northern part of the spawning distribution, the present study provides a good opportunity to describe and examine the spawning and larval habitat for these species.
Aside from depth, the physical habitat characteristics of different larvae are relatively restricted, particularly for Thunnus larvae. The temperature range $\left(>24^{\circ} \mathrm{C}\right)$ where Thunnus larvae were captured agrees with that from other studies (Richards \& Simmons 1971, Davis et al. 1990b). In a geographic survey, McGowan \& Richards (1989) showed that larvae of bluefin tuna $T$. thynnus were restricted to very limited bounds of surface temperature and salinity as compared to the range sampled; they suggested that the larval habitat could be characterized by conditions of temperature, salinity, prey, predators, and circulation patterns conducive to larval retention. The seasonality observed in this study is related to the availability of appropriate spawning habitat, since larvae are present year-round in equatorial waters (Matsumoto 1966). If the larval habitat can indeed be characterized by specific features of depth, temperature, and salinity, it may be possible to evaluate the likelihood of tuna spawning in different areas. While waters containing larvae are an approximation of the spawning habitat of adults, proper physical conditions cannot assure the presence of larvae. For example, Thunnus spp. were present in only $32.5 \%$ of the 203 samples meeting the bounds of depth, temperature, salinity, and sigma-t shown in Table 1. The corresponding figure for Katsuwonus pelamis was $15.8 \%$ (of 336 samples) and for Auxis spp. $22.3 \%$ (of 341 samples).

Among the taxa considered in this paper, Auxis spp. showed the greatest range of temperature and salinity, principally due to the high abundance in April (Fig. 2, Table 1); they were present in low abundance in the 2 warmest months, extremely rare in December when water was at intermediate temperatures, but most abundant in April, the coldest month sampled (Fig. 8). Although the spawning seasons of $A$. thazard and $A$. rochei in Hawaii are unknown (Collette \& Nauen 1983), the marked difference between the physical features of waters where larvae of this genus occurred (September and June versus April) may have been related to temporal spawning patterns of the 2 species, with one species dominant in the cooler waters of April. In other regions of the northern hemisphere where information exists on seasonal spawning of Auxis, A. rochei spawns primarily in February to September, while $A$. thazard spawns primarily from August to April (Collette \& Nauen 1983). It is thus possible that April collections may be dominated by $A$. thazard and July and September by A. rochei larvae.

Temperature plays an important role in the observed distribution for all 3 genera, in the vertical dimension (Fig. 9) as well as over horizontal scales (Figs. 10 \& 11). Although surface temperatures were warmer in September than June (Fig. 8), the thermocline was generally deeper in June and the weighted mean depths of 
occurrence for all 3 genera were greater than in September. At Johnston Island, where the thermocline is even deeper than off Oahu, Boehlert et al. (1992) observed larvae of Thunnus spp. at depths greater than $50 \mathrm{~m}$ and of Katsuwonus pelamis deeper than $100 \mathrm{~m}$

Diel vertical migration was not evident for any of the taxa in this study (Figs. 5 to 7 ). This contrasts with other work; the dominant pattern described for the genus Thunnus is shallow distribution during the day and dispersal throughout the mixed layer during the night (Richards \& Simmons 1971, Davis et al. 1990a). For Katsuwonus pelamis, Davis et al. (1990a) observed movement out of surface waters in daytime. Although a first glance at the day versus night distribution of Auxis spp. larvae at the nearshore windward station in April might suggest nighttime dispersal, it was related to physical structure of the water column and probably advective water mass movement (Fig. 9); larval distribution relative to sigma- $t$ did not change markedly. Similar changes in depth distribution of Thunnus maccoyii relative to changes in the water column were seen over time by Davis et al. (1990a). Our results do not support strong contributions of larval behavior to patterns of vertical distribution; instead, the buoyancy of larvae may play an important role. This is supported by the very low coefficient of variation for sigma- $t$, compared to temperature, in water where larvae were present (Table 1). Vertical distribution of early larvae of haddock Melanogrammus aeglefinus is dictated by buoyancy changes of the egg during the embryonic period (Frank et al. 1989). Similarly, Sclafani et al. (1993) suggested that patterns of vertical distribution of cod Gadus morhua larvae in the field could, to a first approximation, be explained by buoyancy and condition factor independent of behavior.

\section{Relationship of scombrid larvae to islands}

The distribution of fish larvae around islands has been studied for many species, typically concentrating on demersal, island-associated taxa (Lobel \& Robinson 1988, Boehlert et al. 1992, see review in Boehlert \& Mundy 1993). Yellowfin tuna Thunnus albacares, which likely comprise the majority of larval Thunnus spp. collected in our study, may be island-associated; Murphy \& Shomura (1972) stated that '...the occurrence of young yellowfin tuna in the central Pacific is intimately related to the presence of land'. They also noted that large $(>120 \mathrm{~cm})$ yellowfin are more abundant near islands than in oceanic waters. Larval tunas also show distinct distributional patterns relative to land (Miller 1979, Leis et al. 1991). The 3 principal taxa in this study showed differing patterns of distribution relative to the island (Figs. $3 \& 5$ to 7 ). Thunnus spp. showed very high abundance at the nearshore leeward station as compared to other areas. Auxis spp. was in lower abundance at the 2 stations farthest offshore than at the 4 nearshore stations, although stations beyond $30 \mathrm{~km}$ would be needed to determine if this pattern continues farther seaward. Finally, Katsuwonus pelamis abundance increased with distance from the island.

The greater abundance of larval Thunnus spp. near islands has been noted by Miller (1979), Leis et al. (1991), and Nishikawa \& Ueyanagi (1991). Our nearshore leeward sampling station was near where Miller (1979) observed high larval Thunnus abundance. Two mechanisms, retention by eddies and onshore advection, have been proposed to explain the higher larval abundance in leeward waters of Hawaii. Lobel \& Robinson (1988) observed higher $T$. albacares larval abundances inside, as opposed to outside, an eddy off the leeward side of the island of Hawaii, and suggested that mesoscale lee eddies may maintain fish larvae near islands. While we have no evidence for the presence of an eddy during our sampling, the leeward side had a warm, low salinity pool compared to the windward side that may suggest less mixing. Although this pool extended to the farthest offshore station, larval abundance fell off rapidly with increasing distance from shore, suggesting that an eddy of the scale noted in Lobel \& Robinson (1988) was not present. Leis (1982) suggested that our nearshore study area at leeward Oahu was dominated by alongshore flow and smaller tidal eddies up to $3 \mathrm{~km}$ in diameter; this is more consistent with our observations of Thunnus larval distribution (Fig. 3). We thus discount the hypothesis that the distributions of scombrid larvae observed on the leeward coast in our study were maintained by mesoscale eddies.

The second explanation was proposed by Miller (1979), who suggested that the concentration of tuna larvae nearshore was related to upwelling and the associated onshore advection of larvae presumably spawned in offshore waters and distributed in a narrow, relatively deep vertical band. The proposed mechanism for concentration at depth was vertical migration coupled with a lower barrier (presumably thermal) to downward migration. Our sampling does not support either hypothesis. Diel vertical migration was not observed for any of the scombrid taxa studied and although temperature may play an important role in vertical distribution, it does not appear to result in concentration at a lower bound (Figs. 10 \& 11). Although we did not sample in the very nearshore waters studied by Miller (1979), the months with abundant Thunnus spp. larvae were characterized by a warm, low salinity pool on the leeward side. This was absent 
on the windward side, and larval Thunnus spp. were consistently in low abundance there. Thus, like Leis et al. (1991), our data do not support Miller's hypothesis.

We propose an alternative explanation for the high abundances nearshore. That tunas aggregate in selected areas for feeding is well known. While mature-sized yellowfin tuna do not appear to aggregate at surface thermal fronts (Beardsley 1969, Power \& May 1991), they do aggregate around islands (Murphy \& Shomura 1972) and seamounts (Fonteneau 1991). Near tropical islands, abundant forage, including juvenile reef fish, may be available for adult tuna. Reintjes \& King (1953) noted higher abundances of land-associated crustaceans and fishes in the diet of yellowfin tuna captured near land. As shown by longline catch rates, large yellowfin tuna are also more abundant on leeward than on windward sides of Oahu (Shomura 1959, C. H. Boggs, NMFS Honolulu Lab, pers. comm.). Thus, for yellowfin tuna, it is conceivable that increased larval abundance on the leeward side of Oahu is simply related to the attraction and retention of spawning adults to feeding grounds near islands. There may also be active selection of spawning habitat by the adults, which may seek physical conditions that promote higher larval growth and survival. Opportunistic species of fish that produce large numbers of small larvae may depend on high prey production at specific hydrographic features and thus target these locations for spawning (Fortier et al. 1992); this was suggested for bluefin tuna by McGowan \& Richards (1989).

The significance of nearshore concentrations of larval Thunnus spp. around leeward Oahu may similarly be related to suitability for early larval survival. Scombrid larvae are voracious feeders and early larval stages require high concentrations of prey for survival (Hunter \& Kimbrell 1980, Olson \& Scholey 1990); mortality of preflexion scombrid larvae from starvation is high (Margulies 1993). While later stage larvae may be mainly piscivorous, early stages consume mainly crustaceans (Uotani et al. 1990). Young \& Davis (1990) suggested that high densities of larval southern bluefin tuna can locally affect the abundance of microzooplankton prey in the open ocean, pointing out the importance of high prey production rates for early larvae. Primary productivity around islands is often higher than in the open ocean (the 'island mass effect'), particularly around high islands such as Oahu (Gilmartin \& Revelante 1974, Dandonneau \& Charpy 1985). Waters near islands in tropical and subtropical areas may similarly be characterized by increased zooplankton abundance, often of species uncommon in offshore waters (Jones 1962, Hernandez-Leon 1991). In very nearshore waters, insular taxa such as the copepod Undinula vulgaris may occur in high densities
(Leis 1982, Hassett \& Boehlert unpubl.). Thus, greater availability of prey in nearshore waters could result in higher survival rates for early larvae during the stage when growth in the open ocean may be low (Jenkins \& Davis 1990). Theilacker (1986) noted that only $12 \%$ of first-feeding larvae of the carangid Trachurus symmetricus were starving in waters near islands and banks, as contrasted with $70 \%$ in offshore waters; moreover, healthy larvae around islands were characterized as more fit by virtue of greater glycogen stores in the liver. Thus, enhanced survival of early larvae may be the selective factor promoting greater abundance near islands. Postflexion larvae and early juvenile stages of scombrids, which can search greater volumes of water, typically feed on fish larvae and juveniles. Higgins (1970) noted nearly 3 -fold greater abundances of juvenile Thunnus spp. at stations $56 \mathrm{~km}$ offshore of Oahu as opposed to $7 \mathrm{~km}$ offshore. This is consistent with our results showing larger Thunnus larvae with increasing distance offshore, suggesting that larvae disperse from nearshore areas with increasing size (and age).

Skipjack tuna show significant distributional differences from Thunnus as both adults and larvae. Adult skipjack aggregate near thermal fronts (Fiedler \& Bermard 1987), but not necessarily islands. Mean size of skipjack in the Hawail fishery increases in the offshore direction from both leeward and windward Oahu (Uchida \& Sumida 1971), consistent with reduced spawning in nearshore waters. Cayre (1991) noted that tagged skipjack did not remain in the vicinity of fish attraction devices the way that yellowfin did; fish foraging in daylight hours nearshore move offshore in the evening (Yuen 1970). Because spawning occurs around midnight for skipjack (Hunter et al. 1986), larvae are more abundant in offshore waters. Juvenile Katsuwonus pelamis are 11 -fold more abundant $56 \mathrm{~km}$ offshore of Oahu compared to $7 \mathrm{~km}$ offshore (Higgins 1970). In contrast to Thunnus, larval skipjack are less abundant nearshore on both windward and leeward transects. Thus, the spatial distribution of scombrid larvae, and the selective pressures that have given rise to them, appear to differ between genera.

Larval scombrid distributions near Oahu appear to be the product of environmental influences on adult spawning; our results do not strongly support a role of early larval behavior. Spawning by adults establishes the initial, broad distribution of eggs and small larvae, from which the distributions of larger larvae are modified, perhaps by a passive process dependent upon larval buoyancy. The broad distributions were distinct for genera in our study, with different seasonal and onshore-offshore patterns for Auxis spp., Katsuwonus pelamis, and Thunnus spp. On finer temporal and spatial scales, the horizontal and vertical distributions of 
scombrid larvae were closely linked to physical characteristics of water column structure. Little evidence was found for simple, diel vertical migration except movement into or avoidance of the neuston. Instead, the fine-scale distribution of scombrid larvae off Oahu was linked closely to local changes in larval habitat, as defined by the temperature or density structure of the upper thermocline and mixed layer. This paper provides a first description of the physical characteristics of larval scombrid habitats. Future research on the early life history of scombrids near islands should investigate the biological characteristics of larval habitats, to test our hypothesis about the importance of larval survival to these distributions.

Acknowledgements. We thank the crew and scientists of NOAA ship 'Townsend Cromwell' cruises TC-8504, 8505, 8602, and 8604 for their assistance in collecting these samples. C. Fujisawa, J. Sampaga, H. Williams, and R. Yoshimoto (NMFS SWFSC Honolulu) processed the plankton samples in the laboratory. R. Yoshimoto measured the larvae. C. Miller and $R$. Nielsen (Oregon State Univ.) provided the initial MOCNESS data acquisition programs. A. Chung (NMFS SWFSC Honolulu) modified the programs for our system and verified the physical data. We thank Christofer Boggs, Tim Davis, and Jim Uchiyama for reviewing an earlier draft of the manuscript.

\section{LITERATURE CITED}

Batalyants, K. Ya. (1989). On spawning of skipjack tuna (Katsuwonus pelamis L.). ICCAT Collective Volume of Scientific Papers, International Commission for the Conservation of Atlantic Tunas, Secretariat, Madrid, Spain. SCRS/88. 30: 20-27

Beardsley, G. L. Jr (1969). Distribution and apparent relative abundance of the yellowfin tuna (Thunnus albacares) in the Eastern Tropical Atlantic in relation to oceanographic features. Bull. mar. Sci. 19: 48-56

Boehlert, G. W., Mundy, B. C. (1993). Ichthyoplankton assemblages at seamounts and oceanic islands. In: Moser, H. G., Smith, P. M., Fuiman, L. A. (eds.) Advances in the early life history of fishes. Bull. mar. Sci. 53: 336-361

Boehlert, G. W., Watson, W., Sun, L. C. (1992). Horizontal and vertical distributions of larval fishes around an isolated oceanic island in the tropical Pacific. Deep Sea Res. 39: $439-466$

Brown, D. M., Cheng, L. (1981). New net for sampling the ocean surface. Mar. Ecol. Prog. Ser. 5: 225-227

Cayre, P. (1991). Behaviour of yellowfin tuna (Thunnus albacares) and skipjack tuna (Katsuwonus pelamis) around fish aggregating devices (FADs) in the Comoros Islands as determined by ultrasonic tagging. Aquat. Living Resour. 4: 1-12

Collette, B. B., Nauen, C. E. (1983). FAO species catalogue. Vol. 2. Scombrids of the world. An annotated and illustrated catalogue of tunas, mackerels, bonitos, and related species known to date. FAO Fish. Synop. 125, Vol. 2

Collette, B. B., Potthoff, T., Richards, W. J., Ueyanagi, S., Russo, J. L., Nishikawa, Y. (1984). Scombroidei development and relationships. In: Moser, H. G., Richards, W. J., Cohen, D. M., Fahay, M. P., Kendall, A. W. Jr, Richardson, S. L. (eds.) Ontogeny and systematics of fishes. Am. Soc. Ichthyol. Herpetol. Spec. Pub. No. 1, p. 591-620
Conand, F., Richards, W. J. (1981). Distribution of tuna larvae between Madagascar and the equator, Indian Ocean. Biol. Oceanogr. 1: 321-336

Dandonneau, Y., Charpy, L. (1985). An empirical approach to the island mass effect in the south tropical Pacific based on sea surface chlorophyll concentrations. Deep Sea Res. 32: $707-721$

Davis, T L. O., Jenkins, G. P., Young, J. W. (1990a). Diel patterns of vertical distribution in larvae of southern bluefin Thunnus maccoyii, and other tuna in the East Indian Ocean. Mar. Ecol. Prog. Ser, 59: 63-74

Davis, T. L. O., Jenkins, G. P., Young, J. W. (1990b). Patterns of horizontal distribution of the larvae of southern bluefin (Thunnus maccoyil) and other tuna in the Indian Ocean. J. Plankton Res. 12: 1295-1314

Fiedler, P. C., Bernard, H. J. (1987). Tuna aggregation and feeding near fronts observed in satellite imagery. Cont. Shelf Res. 7: 871-881

Fofonoff, N. P., Millard, R. C. Jr (1983). Algorithms for computation of fundamental properties of seawater. UNESCO Tech. Pap. mar. Sci. 44

Fonteneau, A. (1991). Monts sous-marins et thons dans l'Atlantique tropical est. Aquat. Living Resour. 4: 13-25

Fortier, L., Levasseur, M. E., Drolet, R., Therriault, J. C. (1992). Export production and the distribution of fish larvae and their prey in a coastal jet frontal region. Mar. Ecol. Prog. Ser. 85: 203-218

Frank, K. T., Page, F. H., McRuer, J. K. (1989). Hydrographic effects on the vertical distribution of haddock (Melanogrammus aeglefinus) eggs and larvae on the southwestern Scotian shelf. Can. J. Fish. Aquat. Sci. 46: 82-92

Fritzsche, R. A. (1978). Development of fishes of the midAtlantic Bight, an atlas of egg, larval and juvenile stages, Vol. 5. Chaetodontidae through Ophidiidae. U.S. Fish Wildl. Serv. Biol. Serv. Prog. FWS-OBS $78 / 12$

Gilmartin, M., Revelante, N. (1974). The 'island mass' effect on the phytoplankton and primary production of the Hawaiian Islands. J. exp. mar. Biol. Ecol. 16: 181-204

Graves, J. E., Simonvich, M. A., Schaefer, K. M. (1988). Electrophoretic identification of early juvenile yellowfin tuna, Thunnus albacares. Fish Bull. U.S. 86: 835-838

Hernandez-Leon, S. (1991). Accumulation of mesozooplankton in a wake area as a causative mechanism of the islandmass effect. Mar. Biol. 109: 141-147

Higgins, B. E. (1970). Juvenile tunas collected by midwater trawling in Hawailan waters. Trans. Am. Fish. Soc. 99: $60-69$

Hunter, J. R., Kimbrell, C. A. (1980). Early life history of Pacific mackerel, Scomber japonicus. Fish. Bull. U.S. 78: $89-101$

Hunter, J. R., Macewicz, B. J., Sibert, J. R. (1986). The spawning frequency of skipjack tuna, Katsuwonus pelamis, from the South Pacific. Fish Bull. U.S. 84: 895-903

Jenkins, G. P. Davis, T. L. O. (1990). Age, growth rate, and growth trajectory determined from otolith microstructure of southern bluefin tuna Thunnus maccoyii larvae. Mar. Ecol. Prog. Ser. 63: 93-104

Jones, E. C. (1962). Evidence of an island effect upon the standing crop of zooplankton near the Marquesas Islands, Central Pacific. J. Cons. int. perm. Explor. Mer 27: 223-231

Kohno, H., Shimizu, M., Nose, Y. (1985). Geographic variation of the larval skipjack tuna, Katsuwonus pelamis (Linnaeus), from the Pacific Ocean. Bull. Far Seas Fish. Res. Lab., Japan 22: 131-145

Koido, T., Suzuki, Z. (1989). Main spawning season of yellowfin tuna, Thunnus albacares, in the western tropical 
Pacific Ocean based on the gonad index. Bull. Far Seas Fish. Res. Lab., Japan 26: 153-163

Leis, J. M. (1982). Nearshore distributional gradients of larval fish (15 taxa) and planktonic crustaceans (6 taxa) near Hawaii. Mar. Biol. 72: 89-97

Leis, J. M., Trnski, T., Harmelin-Vivien, M., Renon, J. P., Dufour, V., El Moudni, M. K., Galzin, R. (1991). High concentrations of tuna larvae (Pisces: Scombridae) in nearreef waters of French Polynesia (Society and Tuamotu Islands). Bull. mar. Sci. 48: 150-158

Lobel, P. S., Robinson, A. R. (1988). Larval fishes and zooplankton in a cyclonic eddy in Hawaiian waters. J. Plankton Res. 10: 1209-1223

Lloyd, M. (1967). Mean crowding. J. Anim. Ecol. 36: 1-30

Margulies, D. (1993). Assessment of the nutritional condition of larval and early juvenile tuna and Spanish mackerel (Pisces, Scombridae) in the Panama Bight. Mar. Biol. 115: $317-330$

Matsumoto, W. M. (1958). Description and distribution of larvae of four species of tuna in central Pacific waters. Fish. Bull. U.S. Fish. Wildl. Serv. 58: 31-72

Matsumoto, W. M. (1966). Distribution and abundance of tuna larvae in the Pacific Ocean. In: Manar, T. A. (ed.) Proceedings of the Governor's Conference on Central Pacific Fishery Resources, Honolulu-Hilo, February 28-March 12, 1966. State of Hawaii, Honolulu, p. 221-230

Matsumoto, W. M., Ahlstrom, E. H., Jones, S., Klawe, W. L., Richards, W. J., Ueyanagi, S. (1972). On the clarification of larval tuna identification particularly in the genus Thunnus. Fish. Bull. U.S. 70(1): 1-12

Matsumoto, W. M., Skillman, R. A., Dizon, A. E. (1984). Synopsis of biological data on skipjack tuna, Katsuwonus pelamis. NOAA Tech. Rept. NMFS Circ. 451

McGowan, M. F., Richards. W. J. (1989). Bluefin tuna, Thunnus thynnus, larvae in the Gulf Stream off the Southeastern United States: satellite and shipboard observations of their environment. Fish. Bull. U.S. 87: $615-631$

Miller, J. M. (1979). Nearshore abundance of tuna (Pisces: Scombridae) larvae in the Hawaiian Islands. Bull. mar. Sci. 29: $19-26$

Murphy, G. I., Shomura, R. S. (1972). Pre-exploitation abundance of tunas in the equatorial central Pacific. Fish. Bull. U.S. 70: 875-913

Nishikawa, Y., Honma, M., Ueyanagi, S., Kikawa, S. (1985). Average distribution of larvae of oceanic species of scombroid fishes, 1956-1981. Far Seas Fish. Res. Lab., Japan, Ser. 12

Nishikawa, Y., Rimmer, D. W. (1987). Identification of larval tunas, billfishes and other scombroid fishes (suborder Scombroidei): an illustrated guide. CSIRO Mar. Lab. Rep. 186

Nishikawa, Y., Ueyanagi, S. (1991). Morphological development of larvae of longtail tuna. Bull. Nat. Res. Inst. Far Seas Fish. 28: 1-13

Olson, R. J., Scholey, V. P. (1990). Captive tunas in a tropical marine research laboratory - growth of late-larval and

This article was presented by K. Sherman (Senior Editorial Advisor), Narragansett, Rhode Island, USA early-juvenile black skipjack Euthynnus lineatus. Fish. Bull. U.S. 88 : $821-828$

Omori, M., Ikeda, T. (1984). Methods in marine zooplankton ecology. John Wiley and Sons, New York

Power, J. H., May, L. N. (1991). Satellite observed sea-surface temperatures and yellowfin tuna catch and effort in the Gulf of Mexico. Fish. Bull. U.S. 89: 429-439

Reintjes, J. W., King, J. E. (1953). Food of yellowfin tuna in the central Pacific. Fish. Bull. U.S. 54: 91-110

Richards, W. J., Potthoff, T. (1974). Analysis of the taxonomic characters of young scombrid fishes, genus Thunnus. In: Blaxter, J. H. S. (ed.) The early life history of fish. SpringerVerlag, New York, p. 623-648

Richards, W. J., Simmons, D. C. (1971). Distribution of tuna larvae (Pisces, Scombridae) in the northwestern Gulf of Guinea and off Sierra Leone. Fish. Bull. U.S. 69: 555-568

Sclafani, M., Taggart, C. T., Thompson, K. R. (1993). Condition, buoyancy and the distribution of larval fish - implications for vertical migration and retention. J. Plankton Res. 15: 413-435

Seckel, G. R., Yong, M. Y. Y. (1977). Koko Head, Oahu, seasurface temperatures and salinities, 1956-73, and Christmas Island sea-surface temperatures, 1954-73. Fish. Bull. U.S. 75: $767-787$

Shomura, R. S. (1959). Changes in the tuna landings of the Hawaiian longline fishery 1948-1956. Fish. Bull. U.S. 60: $87-106$

Strasburg, D. W. (1960). Estimates of larval tuna abundance in the central Pacific. Fish. Bull. U.S. Fish. Wildl. Serv. 60: 231-255

Theilacker, G. H. (1986). Starvation-induced mortality of young sea-caught jack mackerel, Trachurus symmetricus, determined with histological and morphological methods. Fish. Bull. U.S. 84: 1-17

Uchida, R. N. (1981). Synopsis of biological data on frigate tuna, Auxis thazard and bullet tuna, A. rochei. NOAA Tech. Rept. NMFS Circ. 436

Uchida, R. N., Sumida, R. F. (1971). Analysis of the operations of seven Hawaiian skipjack tuna fishing vessels, JuneAugust 1967. NOAA-NMFS Special Scientific Report, Fisheries, No. 629

Uotani, I., Saito, T., Hiranuma, K., Nishikawa, Y. (1990). Feeding habit of bluefin tuna Thunnus thynnus larvae in the western North Pacific Ocean. Bull. Jap. Soc. scient. Fish. 56: 713-717

Wiebe, P. H., Morton, A. W., Bradley, A. M., Backus, R. H., Craddock, J. E., Barber, V., Cowles, T. J., Flierl, G. R. (1985). New developments in MOCNESS, an apparatus for sampling zooplankton and micronekton. Mar. Biol. 87 : $313-323$

Young, J. W., Davis, T. L. O. (1990). Feeding ecology of larvae of southern bluefin, albacore and skipjack tunas (Pisces, Scombridae) in the Eastern Indian Ocean. Mar. Ecol. Prog. Ser. $61: 17-29$

Yuen, H. S. H. (1970). Behavior of skipjack tuna, Katsuwonus pelamis, as determined by tracking with ultrasonic devices. J. Fish. Res. Bd Can. 27: 2071-2079

Manuscript first received: October 25, 1993

Revised version accepted: January 18, 1994 